\title{
C-E Translation of Jiang Zilong's Short Story $M r$. Big on the Basis of Functional Equivalence Theory
}

\author{
Min Shen \\ Xi'an Aeronautical University, Xi'an, China
}

\begin{abstract}
In recent years, an increasing amount of excellent foreign novels and short stories are translated and introduced into China while limited Chinese short stories are presented overseas. This paper, on the basis of Nida's functional equivalence theory, analyzes and reviews the translated version of the short story "Mr. Big" written by Jiang Zilong through the application of functional equivalence theory from lexical and syntactic level. The translator, with the target language reader at the core, fully comprehends the original text, emotions, style, and mood of the short story, and appropriately uses various translation methods, such as transliteration with annotation and literal translation for translating culture-loaded words; literal translation, liberal translation, supplementary translation, divided translation, adapted translation, conversed translation, etc. to faithfully reproduce the original content and artistic style of the original work, and achieve functional equivalence. This paper is supposed to enhance the foreign understanding of Jiang Zilong's short story and to provide reference and inspirations for Chinese-English translation of novels and short stories.
\end{abstract}

Index Terms - short story, functional equivalence, translation methods

\section{INTRODUCTION}

The translation of short stories can be categorized into literature translation. It requires that the target text should deliver the meaning as well as style of the original text to the maximum; thus, target readers can obtain similar reading and aesthetic experience as the original-text readers, which is consistent with Eugene Nida's functional equivalence theory. Wang Jiayang (2017) holds that "the main characteristics of the short story are: concentrated characters, vivid plots, logical rigor, concise narratives and representativeness. Readers can see how things will develop from the first small beginnings and see the whole picture by one spot. Not only short story can shape typical characters, but also reveal the reality quickly.(p. 4)" This paper, through analysis of the short story and target language, discusses translation methods applied in the translation for reference and to improve the accuracy and promote the communications in different cultures.

\section{BRIEF INTRODUCTION OF THE AUTHOR AND THE SHORT STORY}

Jiang Zilong, the former vice president of Chinese Writers' Association and President of Tianjin Writers' Association. His work started to appear in print since 1962. His works, the Story of Director Qiao's Taking Post published in 1979, the Diary of a Factory's Secretary in 1980, Wishing Happy New Year in 1982 won the National Award for Excellent Short Story; his works, the Trailblazers published in 1980, Rainbow in 1981, Sad Melody of Yan-Zhao Area in 1984 won National Award for Excellent Medium-length Novel. His full-length novels include Snake Deity, the Theory of Zi Wu Liu Zhu, Renqi, Cavity, The Empire of Farmers and he writes hundreds of medium-length novels and essays. In 2010, his collected works including 14 volumes were published by people's Literature Publishing House.

Mr. Big, one of the short stories written by Jiang Zilong, portrays an old and stubborn Tianjin calligrapher Mr. Big, who feels free and confident and has his own way to make himself the center of good Feng Shui in the nineteen eighties. From Mr. Big, readers can have a glimpse of a common old craftsman's life in Tianjin, China in the nineteen eighties.

\section{THEORETICAL GUIDANCE}

Eugine A. Nida (1964) assumes that "there are fundamentally two different types of equivalence: one which may be called formal and another which is primarily dynamic. (p. 164)" Later Nida (1993) prefers to use the expression "functional equivalence" and he believes that "the readers of a translated text should be able to comprehend it to the point that they can conceive of how the original readers of the text must have understood and appreciated it. (p. 127)". Nida and Taber (1969) define that "translating consists in reproducing in the receptor language the closest natural equivalent of the source-language message, firstly in terms of meaning and secondly in terms of style" (p. 12). Nida's "functional equivalence" stands for communicating effectively the source language message, namely, reproducing "the closest natural equivalent" to the source language message in the receptor language. Generally speaking, translation is not always a perfect art and meaning must have priority over style. Nida's functional equivalence theory provides new 
standard for translation, and has significant impact on translation circles.

\section{Application of FunCtional Equivalence TheORY In TRANSLATion}

Functional Equivalence at the Lexical Level

a. Translation of culture-loaded words

According to Nida's theory, the translator should use three aspects of equivalence as the principle of translation and accurately reproduce the cultural connotation of the source language in the target language through three methods. The first one is lexical equivalence; the second one is syntactical equivalence; the third one is discourse equivalence (p. 231).In these three aspects, Nida thinks meaning is the most important and form comes the second.

Newmark (2001, p. 94) defines culture as "the way of life and its manifestations that are peculiar to a community that uses a particular languages as its means of expression". Bassnett (2010) points out that language is the "heart" within the body of culture (p. 22). Wang Dechun (1990) defines culture-loaded words as "words which are related to China's politics, economics, history, culture and social customs and thus possess national culture characteristics." (p. 6-8).

From a macro perspective, there are two translation strategies: domestication and foreignization for translating culture-loaded words. Based on the above two strategies, the specific translation methods are transliteration with annotation and literal translation.

Transliteration with annotation

Example 1: 风水

Translation: Feng Shui (the location of a person's house supposed to have an influence on the fortune of a family and his / her offspring)

Example 2: 太极

Translation: Tai Chi (great ultimate)

Example 3: 磕头

Translation: kowtowing

For culture-loaded words, related cultural connotations ought to be translated. The translator must strive to promote the spread of Chinese culture and enhance and demonstrate the soft power of Chinese culture. With increasing international cultural exchanges, more and more Chinese culture-loaded words have been transliterated overseas and accepted and understood by readers in English-speaking countries, for the translation of these vocabularies, annotation can be omitted. For some of words not that popular among foreigners, they require explanation in bracket just like Feng Shui and Tai Chi.

Literal translation

Example 4: 单布裤补

Translation: old-fashioned blouse and trousers

Example 5:牌㻞

Translation: plaque

Example 6:灵位

Translation: tablet

Example 7: 一千刀

Translation: 100,000 pieces of Xuan paper

Example 8: 卖字

Translation: sell the calligraphy

Example 9: 太师椅

Translation: an old-fashioned Chinese wooden armchair;

In Chinese, “单布裤褂” is a kind of typical traditional Chinese clothing while “太师椅” a kind of traditional Chinese furniture, and the addition of “old-fashioned” will help foreign readers to understand. The translation of “牌匾” “灵位” is alienated as "plaque" and "tablet" respectively. “一千刀” means "100,000 pieces of Xuan paper" in the context not “100,000 US dollars" and “卖字” refers to "sell the calligraphy".

b. Functional equivalence at the syntactical level

In discussing translation process, Nida (1964) puts forward four necessary translating processes: analyze, transfer, restructuring and testing (p. 179). The first translation step is to analyze the referential and conceptual meaning of words, study the grammar and syntax and the textual structure of the source text and divide the sentence structure by finding the "kernel sentence" and other "branch sentences". The second step is to transfer information from the source language to target language, which mainly proceeds in a translator's brain. The third step "restructuring" indicates order change of information such as modifiers and modified terms. And the final step "testing" is mainly about how the potential readers reflect to the translation. Nida (2004) opines that the "testing" should basically include accuracy and readability of the translation and the equivalence of style. The key of "testing" is dynamic equivalence of the source text rather than the word-to-word equivalence (p. 163).

Liberal translation 
Example 10: 不错, 家里的钱的确都是他挣的, 可挣大钱的男人有的是，没有像他这么毒的。

Translation: It is true that he is the moneymaker of the family, yet unlike other breadwinners, he controls money in a quite mean way.

Example11:整个上午, 他睡觉, 家也死了。

Translation: He sleeps for a whole morning and so does the house.

Liberal translation is also called free translation, which means the source text is not translated word for word but more flexible on the basis of comprehending the source text. Nida (1978) opines that if a translation is to meet the four basic requirements: making sense; conveying the spirit and manner of the original; having a natural and easy form of expression; and producing a similar response, it is inevitable that at one point the controversy between content and form will be severe so that one or the other must give away. Sometimes, the formal equivalence has to give way for equivalence of information and style. Literally this sentence means "it is true that he earns all the money for the family, and quite a lot of men earn a lot of money, but unlike them, he is very "poisonous". In translating, this wordy translation is not adopted. The translator uses "moneymaker" to describe Mr. Big and compares him with other "breadwinners" and omits information of "making a lot of money" as "breadwinner" can be a better reference for comparison. The accurate understanding of "毒" is "mean" or "cruel" instead of "poisonous", the translator chooses "mean" to describe Mr. Big's attitude towards money and adds the phrase "control money" to picture a vivid portray of an old man who is mean with money to convey a natural and easy form of expression and produce a similar response for target readers (p. 121). The second sentence literally means for the whole morning to noon, Mr. Big has been sleeping and the house is "dead". However, readers may be stunned and confused by the expression "dead" and a house can never die as it never lives. This sentence depicts that after Mr. Big falls asleep, the house is as quiet as being "dead". To maintain the rhetoric personification in a natural and relaxing way, the translator keeps the rhetoric expression by describing that the house also falls asleep and to avoid repetition, "so does the house" is applied.

Literal translation

Example 12: 墨香腾溢, 他深吸两口。眼神突然清昫, 注视着展开的宣纸, 耳闻清籁, 渐渐进入他所热爱所需 要的那种境界。

Translation: He breathes in the sweet smelling of the ink deep in his lungs. Glaring at the open Xuan paper (a high quality rice paper made for traditional Chinese painting and calligraphy) with sudden piercing eyes, winds whispering in his ears, he is gradually lost in his own beloved world while the outside voices seem to fade away.

Example 13: 大先生活得轻松、自信。别人比不了也学不了。他有办法让好风水老围着自己转。

Translation: Mr. Big feels free and confident. No one rivals him nor can be him. He has his own way to make himself the center of good Feng Shui.

Literal translation is also called direct translation which implies a source text is literally translated into target text without changing structure, word sequence or grammatical units of the source text. These two examples are equivalent to the original text in terms of word sequence, sentence structure and meaning as well as rhetoric devices which are translated into Chinese word for word. It is natural that all translations keep the original content and form to achieve functional equivalence and similar reader response.

Supplementary translation

Example 14: 在他写字台对面的墙上把恩师何匡人的灵位摆在正中间, 左边挂着盖有市长大印的特聘他为一级 书法家的证书，右边是他父母的灵位。这就是他在这个世界上最尊敬的四个人。

Translation: Across the wall of his writing desk sets a shrine including three memorial tablets and one certificate: right in the middle stands his teacher HE's tablet; on the left stands his first-class calligraphy certificate with seals of mayor of Tianjin; on the right stand his parents' tablets. These are the four most respected "persons" for him.

While proposing the concept of "dynamic equivalence", Nida (2013) also advocated a simplified "three-step" translation process: firstly analyze the source sentence and deverbalize its surface structure and find the kernel structure. Secondly transform the kernel structure into its equivalent target language. Thirdly reorganize and restructure the syntactic information. To summarize, it is a process from analysis to reorganization (p.131). In these two sentences, the last sentence is “这就是他在这个世界上最尊敬的四个人” which literally means “these are the four most respected people for him in this world", but in fact the context tells us one of them is a certificate not a "person". In the eyes of Mr. Big, the certificate with seals of mayor of Tianjin, as recognition of his calligraphy, is also the most important part of his life, which is why the translator adds quotation marks to "person". The original text directly describes the four locations between Mr. Big's teacher HE, the certificate and his parents. The translator adds a kernel sentence "across the wall of his writing desk sets a shrine including three memorial tablets and one certificate" to govern the whole sentence and then introduce locations of different objects in details. The compact and well-layered structure is in line with English expression habits, and makes the information clarified.

Divided translation

Example 15: 这是一间少说也有百年历史的旧平房, 与其配套的家具大多也是老式的: 一张高大的旧床, 一把 油漆剥落的太师椅, 旧桌子, 旧発子, 唯色彩生硬的写字台好像是解放后的产物, 上面铺着沾有墨迹的毡子。

Translation: The house in which they live is a bungalow with at least a-hundred-year history, with old-fashioned furniture in it: a huge and high bed, an armchair with flaking paintings, old tables and chairs. Only a bright-colored 
writing desk covered by an ink-stained felt, is a rather new product after China's Liberation (in 1949).

The author emphasizes the bright-colored writing desk to exhibit its difference from other old furniture. In translating, the translator mainly applies literal translation for the first half of the sentence, and splits “唯色彩生硬的写字台好像 是解放后的产物, 上面铺着沾有墨迹的毡子” which literally means “only a bright-colored writing desk covered by an ink-stained felt, is a rather new product after China's Liberation" into another sentence. The translator adapts the information order: put the description of the writing desk to the front and adds the age of the writing desk "in 1949" to help foreign readers be more aware of Mr. Big's living environment and time of furniture to better understand the figure in that era.

Example 16: 不以万变应万变, 不以不变应万变, 人生三大法则是知变、应变、适变, 守住自己的太极, 一动 一静俱浑然。

Translation: He never fights changes with changes, nor changelessness with changes. There are three principles for life: being aware of, reacting to and adapting to changes. A person should guard his or her own Tai Chi (great ultimate) with changes and changelessness.

Sometimes the components of a long sentence are not closely linked in meaning or not closely related, the translator may divide the long sentence into several independent short sentences which are connected by logic rather than grammar marks for syntactic equivalence. With deconstructing, the source and target text may be more equivalent in terms of content and readers' reactions can be further equalized. Though this Chinese sentence focuses on discussing changes and changelessness, it can be divided into three independent sentences on the basis of coherence. In the first short non-subject sentence, the translator adds "he" as a subject, illustrating Mr. Big's attitude toward fighting changes. The second short sentence talks about three principles related to changes. The translator adds "a person" as its subject and translate “一动一静” into "changes and changelessness" through analyzing the referential and conceptual meaning of “动” “静” within the context for lexical equivalence.

Adapted translation

Example 17: 电视台最后一个频道一声“再见”, 就像军营吹响了熄灯号, 院子里立刻静了下来。人们不论活得 有滋有味还是没滋没味, 都开始进入睡眠状态。

Translation: "Goodbye" from programs of the late night TV channel is a military horn for people living in the yards. On hearing it, they, no matter what kind of life they have, soon quiet down and go to bed.

Nida (1986) holds the view on "functional equivalence" as "in translation functional equivalence should be achieved between two languages rather than rigid correspondence of words" (p. 124). The main purpose of adapting is to make the translation more natural and consistent with the target language expression habits. Through reordering, the author abandons the translation of "formal equivalence" to some degree, but gives priority to the equivalence of "content" and "reader response." This is a concession of "formal equivalence" for "content equivalence" mentioned by Nida. Thus, necessary adaptation of information is required in translating, which makes the target sentence more logical and coherent. Literally, “就像军营吹响了熄灯号, 院子里立刻静了下来” means “the military horn sounds as a signal and the yard becomes quiet at once", but to combine the second sentence, the translator adapts the information into "people's reactions on hearing the horn rather than it sounds." Besides, the translator moves the information of “院子里立刻静了下来” which literally means "the yard soon becomes quiet" to the end of the sentence to combine it to “都开始进入睡眠状态” which literally means “people start to fall asleep” and translates it into "soon quiet down and go to bed" for clarification. In the second sentence, "they" as a pronoun, refers to people who live in the yards. This sentence, instead of duplicating the original order, achieves content equivalence in syntactic level via adapting and reconstructing

Conversed translation

Example 18: 正像现代人一看到“望海楼”三个大字，就会想到他老师何匡人并肃然起敬。

Translation: Just like one sight of the most outstanding calligraphy work written by his teacher, the figure HE Kuangren will occur to people in Tianjin to whom they show high respect.

Conversion is a translation strategy applied for better readability and coherence in the target text. Since English and Chinese have different language features, the part of speech of words or phrases in Chinese may have to be converted into a different one in English for natural and closest translation effect. In the source text, the Chinese verb expression “一看到” which means "seeing" is conversed into a preposition expression "on the sight of".

\section{CONCLUSION}

Functional equivalence theory emphasizes the "closeness" of the source and target text, not the exact and ultimate equivalence. Thus, the "equivalence" is just a category. The functional equivalence is further divided into the minimal level and maximal level. Perfect translation may never exist, but for the purpose of readers' comprehension and appreciation, the translator should cultivate aesthetic consciousness, acquire more translation strategies and theoretical guidance for translating. 


\section{REFERENCES}

[1] Bassnett, S. (2010). Translation Studies (Third Edition). Shanghai: Shanghai Foreign Language Education Press.

[2] Jan de Ward \& Nida, E. (1986). From One Language to Another: Functional Equivalence in Bible Translating. Nasbville: Thomas Nelson Publishers.

[3] Newmark, P. (2001). A Textbook of Translation. Shanghai: Shanghai Foreign Language Education Press.

[4] Nida, E. (1964). Toward A Science of Translating. E. J. Brill: Leiden.

[5] Nida E. \& Charles R. T. (1969). The Theory and Practice of Translation, With Special Reference to Bible Translating. Leiden: E. J. Brill.

[6] Nida, E. (1978). Language, Culture, and Translation. Shanghai: Shanghai Foreign Language Education Press.

[7] Nida, E. (1993). Language Culture and Translating. Shanghai Foreign Language Education Press: Shanghai.

[8] Nida, E. \& Charles, T. (2004). The Theory and Practice of Translation. Shanghai Foreign Languages Press: Shanghai.

[9] Nida, E. (2013). Towards a Science of Translating. Shanghai: Shanghai Foreign Language Education Press.

[10] Wang, D. C. (1991). Semantics of national idioms and Dictionary of Chinese Idioms, Research of Dictionary.

[11] Wang, J. Y. (2017). A report on translating a short story—Blood Ties, Hunan university. p. 4.

Min Shen was born in Ningxia, China in 1991. She is currently an assistant in Xi'an Aeronautical University, Xi'an, China. Her research interests cover translation and English teaching. 